\title{
The New FTZs and the Renewed Negative List in China
}

Keyao Zhang*

Beijing Correspondent

\section{Opening New FTZs}

Seven new free trade zones ("FTZs") were unveiled in China on April 1, 2017 by the State Council of China, bringing the total FTZs across the country to 11. These new zones are the third set of FTZs, locating in the provinces of Liaoning, Zhejiang, Henan, Hubei, Sichuan and Shaanxi together with Chongqing Municipality. ${ }^{1}$ It combines registration, administrative services and custom services in one place. ${ }^{2}$

The expansion comes nearly four years after China launched its first FTZ in Shanghai in September 29, 2013. And in late 2014, Tianjin, Fujian and Guangdong were approved to set up the second group of FTZs. ${ }^{3}$ The government hopes the new zones will play a pioneering role, replicating the success of previous trial. The FTZs zones should help promote the nation's key regional and inter-regional development strategies. ${ }^{4}$

Located at the junction of China's Silk Road and Yangtze River economic belts, the Chengdu International Railway Port, a vital part of the China (Sichuan) Pilot Free Trade Zone, is the backbone of the region's plan to establish a global logistics system and booming trade with countries along the route of the B \& R Initiative, striving to be a center for international trade in Southwest China. ${ }^{6}$ 
Figure 1: Three Sets of FTZs in China ${ }^{5}$

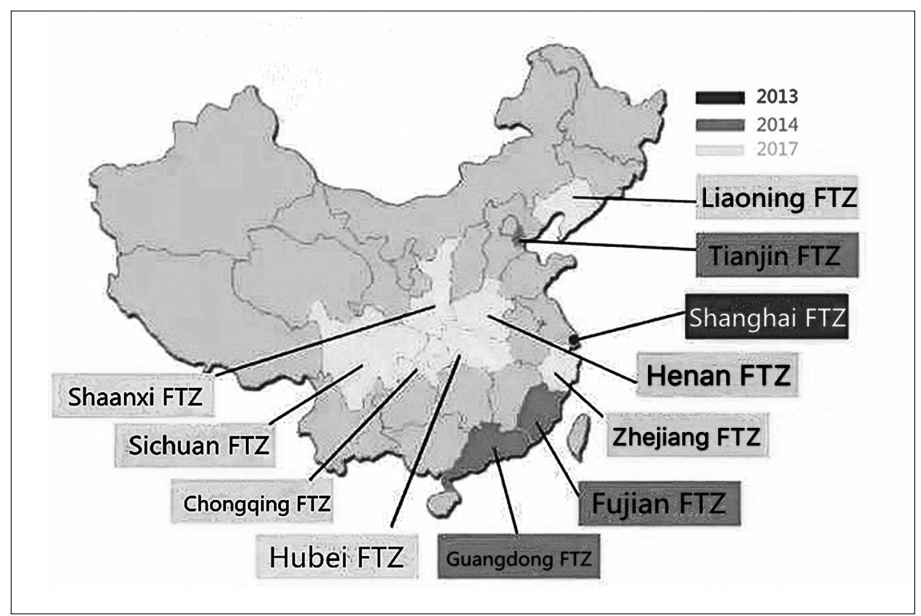

\section{Negative List}

Setting up pilot FTZs is to test a broad range of economic reforms, including increased openness to foreign investment and fewer restrictions on capital flows. ${ }^{7}$ Chinese Premier Li said in the Dalian FTZ, Liaoning Province: "Foreign and domestic investors must be treated on an equal basis, with equally convenient business procedures." ${ }^{8}$ Close to Japan, North and South Korea and Russia, the Liaoning Pilot Free Trade Zone aims to opening-up to and cooperating with Northeast Asia. ${ }^{9}$

The first two sets of zones have successfully introduced a 'negative list,' which specified the investment sectors off-limits to foreign investors and allowed industries not on the list to follow the same investment rules as domestic firms. ${ }^{10}$ The negative list provides an outline of the sectors in which foreign investment is restrained and is applicable to China's FTZs equally. ${ }^{11}$ To further ease investment access, the State Council on June 16 released a new foreign investment negative list for FTZs. The new management measures on foreign investment access took effect on July 10, replacing the old one issued in April 2015. ${ }^{12}$

This year, China has significantly trimmed its negative list. Today, the negative list covers 15 sectors, such as mining, leasing and commercial services, 
manufacturing, wholesale and retail, financing, etc. Among the sectors, 40 categories and 95 special management measures are included, ${ }^{13}$ while there were 190 items on the list in 2013 which increased to 139 in 2014. The Ministry of Commerce has also promoted transparency of the negative list to help facilitate foreign investment. ${ }^{14}$

Compared to the 2015 list, it cuts 10 categories and 27 measures concerning such fields as aviation manufacturing, waterway transportation, banking services and education. ${ }^{15}$ E.g., overseas investors can now design and produce civil helicopters with a maximum take-off weight of 3 metric tons and above in the FTZs. ${ }^{16}$ The Shaanxi Pilot Free Trade Zone issued permits to foreign investors to establish all-around financial service companies. Such favorable policies are a clear indication that the government is supporting Xi' an, the capital city of Shaanxi, in tapping the B\&R opportunities. ${ }^{17}$

Fields not covered by the negative list, including national security, public order, public culture, financing regulation and government purchases, should follow existing regulations. For the non-prohibited investment sectors on the list, a foreign investment permit is necessary, said the circular. For all industries not listed in the document, foreign investors will receive equal treatment as domestic companies in China's FTZs. ${ }^{18}$

According to the 2016-2020 plan released by the State Council in January 2017, China was expected to establish unified and transparent market access rules and boost reform in the commercial registration system to improve market access. China's FTZs are a way of testing new policies, including interest rate liberalization and fewer investment restrictions, to better integrate the economy with international practices. ${ }^{19}$

\section{REFERENCES}

1. See More free trade zones to open in China, XINHUANET, available at http://news.xinhuanet. com/english/2017-03/31/c_136174888.htm (last visited on Aug. 7, 2017).

2. Yue Zhang, In Dalian, premier calls for increased investment, ChinA DAILY, June 29, 2017, available at http://africa.chinadaily.com.cn/business/2017-06/29/content_29926872.htm (last visited on Aug. 7, 2017).

3. See More free trade zones to open in China, XINHUANET, available at http://news.xinhuanet. 
com/english/2017-03/31/c_136174888.htm (last visited on Aug. 7, 2017).

4. Id.

5. See Seven FTZs were newly set up by the State Council, a new round of the policy [国务 院新设7个自贸区, 新一轮的政策红利], available at http://news.lfang.com/17/0417/1019/ 20170213763.html (last visited on Aug. 7, 2017).

6. Zhuan Ti, Chengdu railway port to be intl hub for logistics, ChInA DAILY (Europe), May 12, 2017, available at $\mathrm{http}: / /$ europe.chinadaily.com.cn/epaper/2017-05/12/content_29314996.htm (last visited on Aug. 7, 2017).

7. Supra note 1.

8. Supra note 2.

9. Mengxing Song \& Xiaomin Zhang, Liaoning FTZ acts as portal to emerging regional markets, China Daily, June 28, 2017, available at http://africa.chinadaily.com.cn/china/ 2017-06/28/ content_29915455.htm (last visited on Aug. 7, 2017).

10. Supra note 1.

11. See China opens wider to foreign investors with shortened FTZ negative list, XINHUANET, available at $\mathrm{http}: / / \mathrm{www}$.chinadaily.com.cn/business/2017-06/22/content_29849188.htm (last visited on Aug. 7, 2017)

12. State Council of PRC, China introduces new negative list for FTZ foreign investment, available at http://english.gov.cn/policies/latest_releases/2017/06/16/content_281475687 826506.htm (last visited on Aug. 7, 2017).

13. Id.

14. Supra note 11.

15. Supra note 12.

16. Supra note 14.

17. Evelyn Yu, Xi' an finance house offers hand in B\&R push, CHINA DAILY (USA), available at http://usa.chinadaily.com.cn/china/2017-07/14/content_30120407.htm (last visited on Aug. 7, 2017).

18. Supra note 12.

19. Supra note 14. 